УДК 343.2

\title{
Т.П. Евсеенко
}

\section{К ДИСКУССИИ О ПЕРСПЕКТИВАХ ЭВОЛЮЦИИ РОССИЙСКОГО САМОДЕРЖАВИЯ В БУРЖУАЗНУЮ МОНАРХИЮ (НА ПРИМЕРЕ СУДЕБНОЙ РЕФОРМЫ 1864 ГОДа)}

В статье рассматривается проблема возможностей к реформированию общественного и государственного строя российским самодержавием. На примере Судебной реформы 1864 года показываются пределы способности царизма к реформированию. Автор считает сохранение сословного строя в Российской империи главной причиной незавершённости реформ. Стремление любыми средствами сохранить привилегии дворянства не позволяло правительству осознать реальные потребности общества. Не видя возникновения новых общественных классов, правительство не могло обеспечить защиту их интересов. При этом самодержавие навязывало обществу своё понимание его интересов. Такая политика привела к деформации идеологического развития российской буржуазии, сделав её неспособной к самостоятельной защите даже важнейших собственных интересов. Поэтому задачи буржуазно-демократической революции вынуждены были решать уже иные, антибуржуазные силы в ходе социалистической революции.

Ключевые слова: Российская империя, Судебная реформа 1864 года, российский либерализм, сословный строй, суд присяжных, сословные представители в суде.

DOI: $10.35634 / 2412-9593-2020-30-3-375-381$

Следствием разрушения советского государства в 1991-1993 гг. стал тяжелейший идеологический кризис в российском обществе. Одним из проявлений этого кризиса следует считать попытку коренного пересмотра проблем отечественной истории, включая и те, которые, казалось бы, были давно решены. К числу таковых относилась и проблема оценки российской государственности в том виде, в каком она сложилась к началу XX столетия. Речь шла о попытках пересмотреть характеристику государственного строя Российской империи после издания «Манифеста об усовершенствовании государственного порядка» от 17 октября 1905 г. и особенно после принятия новой редакции Основных Законов Российской империи 23 апреля 1906 г. Некоторые исследователи и даже авторы учебников стали трактовать историю последнего десятилетия существования империи как период «конституционной монархии» ${ }^{1}$.

Представляется, что сторонники указанной точки зрения явно переоценили степень буржуазных преобразований, произошедших в тогдашней России. Более верной кажется именно ленинская оценка реформ, инициированных Первой русской революцией, как «второго шага на пути эволюции феодального самодержавия в буржуазную монархию» ${ }^{2}$. Первым шагом в указанном направлении являлись так называемые «Великие реформы», проведённые правительством Александра II, начавшиеся отменой крепостного права и переросшие в целый комплекс мероприятий по модернизации как государственных структур, так и правовой системы империи.

Именно такая оценка наиболее точно отображает реальное состояние дел в то время. Российская империя, безусловно, эволюционировала в сторону современной буржуазной конституционной монархии, но эволюционные процессы эти шли крайне медленно, с постоянными попытками сохранить максимум возможного из отмирающих феодальных порядков. Каждый шаг по пути прогресса производился правящими кругами империи не по доброй воле и не по заранее намеченному плану, а лишь под давлением необходимости. Эта необходимость выступала в различных формах: то в виде усилившегося натиска революционного движения внутри страны, то в виде «внешнего фактора», такого, например, как военные неудачи в Крымской, а позднее в русско-японской войнах.

Этот вынужденный характер реформирования привёл к трагической ситуации, когда правящие круги страны всё время запаздывали с переменами, производя их в минимальной степени, описанной Лениным фразой «шаг вперёд - два шага назад» ${ }^{3}$. Действовать на опережение господствующие классы оказались неспособны, предпочитая лишь судорожно реагировать на вызовы времени. Столь яв-

\footnotetext{
${ }^{1}$ См., напр.: Конституционное право: учебник для бакалавров / отв. ред. В.И.Фадеев. М: Проспект, 2015. С. 61.

2 Ленин В.И. «Крестьянская реформа» и пролетарски-крестьянская революция // Полн. собр. соч. Т. 20. С. 178.

3 Ленин В. И. Шаг вперед, два шага назад // Полн. собр. соч. Т. 8. С. 185.
} 
ная политическая трусость и откровенное нежелание «чрезмерно крутых перемен» были равно характерны как для правящих кругов, так и для противостоящей им буржуазно-либеральной оппозиции, что на первый взгляд не может не вызывать удивления. Ведь если для самодержавия, выражавшего интересы феодального дворянства, ностальгировавшего о минувшем «золотом веке Екатерины Великой», такое поведение представляется нормальным, то либеральная оппозиция искренне стремилась к буржуазному преобразованию страны, а, следовательно, должна была желать радикальных перемен.

На деле отечественный либерализм, даже в самый ранний, «интеллигентский» период его развития, то есть во времена, когда он ещё оставался достоянием небольшой группы либеральных университетских профессоров, не являясь основой программ политических партий, отличался консервативным, даже можно сказать, «охранительным» характером. Достаточно вспомнить труды одного из его «столпов» Б.Н. Чичерина с его идеей «охранительного либерализма», состоящей «в примирении начала свободы с началом власти и закона» 4 . При этом «примирении» Борис Николаевич признавал естественным ограничение свободы, «дабы сделать её совместимой с господствующим порядком» 5 . Столь подчёркнутая лояльность носителей либеральной идеологии к институтам абсолютизма объясняется, на наш взгляд, особенностями исторического развития России.

Так называемая «европеизация России», традиционно воспринимаемая сторонниками капиталистического пути развития страны как несомненное благо, изначально (со времён Петра I) проводилась именно самодержавной властью. В условиях неразвитости капиталистических отношений и при отсутствии в стране класса буржуазии как такового в начале XVIII в. «прогрессистские» функции, обычно выполняемые этим классом, феодальное государство взяло на себя. Поэтому русская буржуазия, в отличие от своих западноевропейских собратьев, изначально формировалась при «государственной опеке» и не воспринимала феодально-монархические институты как нечто чуждое и тем более враждебное себе.

Такое «суперлояльное» отношение к существующему абсолютистскому государству у идеологов отечественного либерализма сохранилась и позднее, в эпоху буржуазных революций. Так, даже самая радикальная из созданных в России либеральных партий - «партия конституционных демократов» (кадетов), состоявшая первоначально в основном из интеллигенции, никогда не ставила под сомнение существующие монархические институты, а вот свой «конституционализм» трактовала достаточно расплывчато. Не случайно один из её лидеров П.Н. Милюков прямо заявлял: «Мы не оппозиция Его Величеству, мы - оппозиция Его Величества» ${ }^{6}$. В этих условиях не приходится удивляться ещё более «промонархической» позиции их более «осторожных» коллег из «праволиберального» «Союза 17 Октября», которые даже сам царский Манифест от 17 октября 1905 г. «Об усовершенствовании государственного порядка» трактовали не как конкретные обещания скорейших преобразований со стороны царской власти, а как некую конституционную программу, которая в полном объёме ещё только будет реализована где-то в отдаленном будущем, «в надлежащее время».

Подобный подход означал одно: либерально-буржуазная оппозиция абсолютизму сама обрекала себя на простое реагирование на происходящие перемены. Она. подобно правящей верхушке. «тащилась в хвосте событий», вместо того, чтобы выступать их инициатором. В такой роли представить либеральную буржуазию лидером перемен, неважно реформистского или революционного характера, было просто невозможно.

Но страна менялась, и её модернизация становилась неизбежной. А фактический отказ либералов эту модернизацию возглавить просто означал, что необходимые преобразования должны будут произвести иные социальные силы. Свято место, как известно, пусто не бывает. Упорное сопротивление надвигающимся переменам со стороны правящей элиты и трусость либеральной буржуазии в итоге сделали неизбежной социалистическую революцию в России - в стране, которая отнюдь не входила в число «самых передовых» в мире.

В современном отечественном обществоведении всячески проводится мысль о «нежелательности» революционных переворотов. Причём критики революций вполне справедливо обращают внимание на такие негативные стороны революций, как огромные издержки во всех сферах обществен-

\footnotetext{
${ }^{4}$ Чичерин Б.Н. О народном представительстве. М., 1866. С. 490.

${ }^{5}$ Там же.

${ }^{6}$ Выражение лидера партии кадетов Павла Николаевича Милюкова (1859-1943) из его речи, произнесенной (19 июня 1909 г.) на завтраке у лорд-мэра Лондона (в период пребывания делегации Государственной думы в Англии). URL:https://dic.academic.ru/dic.nsf/dic_wingwords/1949/Оппозиция
} 
ной жизни, которые порой ведут «к большой крови». Но они при этом, как правило, забывают, что революции несут в себе и огромный положительный заряд, «расчищая почву» для формирования новых общественных отношений, а главное, что альтернативой революционным переменам часто является стагнация и загнивание общества и государства, которые зачастую становятся причиной издержек, как минимум, не меньших, чем при революционных потрясениях.

Именно с этих позиций следует подходить к истории буржуазного реформирования Российской империи второй половины XIX - начала XX столетия. Реформы, проведённые в годы царствования Александра II, имели целью устранить выявившуюся в годы Крымской войны отсталость Российской империи по сравнению с передовыми государствами Западной Европы, а также обеспечить ускоренное социально-экономическое развитие страны. Составной частью политики нового императора являлась судебная реформа. В отличие от таких реформ, как отмена крепостного права, реорганизация полиции и органов местного самоуправления, её проведение могло показаться легким и беспроблемным, поскольку относительно её необходимости в обществе существовал своеобразный консенсус. Существующая судебная система не устраивала как сторонников преобразований, так и консерваторов и даже самых ярых ретроградов. «Судьи, особенно низшие, до крайности дурны», - констатировал сенатор К.Н. Лебедев ${ }^{7}$. Ревизия судов 36 губерний, проведенная в 1848-1850 гг., подтвердила этот вывод. Волокита, несоблюдение элементарных предписаний закона, бюрократизм являлись неотъемлемыми качествами дореформенной судебной системы. Тип юридически безграмотного, а зачастую и просто коррумпированного судьи формировался всей системой правосудия. Ю.Ф. Самарин вспоминал, как поступив на службу в Сенат, он получил задание составить сенатское определение. Он подготовил квалифицированное определение, «исчерпывающее дело и дающее ему самое правильное по закону и прекрасно мотивированное разрешение по существу» ${ }^{8}$. Обер-секретарь, ознакомившись с ним, призвал Самарина и сказал ему: «Я знаю, что ты умен и честен, и вижу, что ты превосходно разобрал трудное дело по существу, но что и для кого ты написал и что представил мне по начальству? Это умная и ученая диссертация, за которую университет может удостоить степени доктора, но это не проект сенатского определения. Ты забыл самое главное, а именно, что сенатор глуп и не поймет, а вот посмотри, как я переделываю твою работу и тогда всякий ее поймет» 9

Кризисное состояние, в котором находилось правосудие, приводило к неэффективности судебной репрессии. «Суд выносил обвинительные или оправдательные приговоры в отношении всего 12,5 \% подсудимых по уголовным делам. Для остальных 87,5\% рассмотрение их дел заканчивалось "оставлением в подозрении"» ${ }^{10}$. Дамоклов меч правосудия зачастую падал на людей случайных, которые просто не были способны увернуться от него. Поэтому упрощение судебной системы и повышение её эффективности были практически всеобщим требованием.

Возможно, именно поэтому сравнительно радикальный характер реформы был воспринят обществом «на ура», то есть практически без серьёзного сопротивления. В результате за Судебной реформой 1864 г. в отечественной науке закрепилась репутация наиболее полной из всех проведённых в жизнь. В литературе именно её, как правило, демонстрируют в качестве образца последовательного проведения в жизнь новых, буржуазных по сути, принципов. Тем более неожиданным представляется обнаружение следов «непоследовательности» в этой «самой последовательной буржуазной реформе». Причём непоследовательности именно в том, что считается главной положительной чертой реформы - в закреплении этих самых новых принципов. Сохранение в ней элементов, явно отживших своё, «тянущих назад» и противоречащих прогрессивному развитию как страны, так и её судебной системы.

Известно, что к числу важнейших элементов феодального прошлого, которые правительство Александра II так и не решилось ликвидировать, относилось сохранение в стране сословного деления её жителей. Речь идёт не только об абсурдности сохранения в капиталистическом обществе неравенства граждан перед законом как юридического принципа, но также и о том, что окончательно закреплённое реформами Екатерины II в последней четверти XVIII столетия сословное деление российских подданных просто не соответствовало их реальному статусу и роли в социальной и экономической

\footnotetext{
7 Лебедев К.Н. Записки // Русский архив. 1910. № 11. С. 485.

${ }^{8}$ Семенов-Тян-Шанский П.П. Мемуары. Т. 3: Эпоха освобождения крестьян в России (1857-1861 гг.) в воспоминаниях бывшего члена-эксперта и заведовавшего делами Редакционных Комиссий. Пг.: издание семьи, 1915. C. 173.

9 Там же.

${ }^{10}$ Дедов И. Н. История государства и права СССР. Свердловск: СЮИ, 1971. Ч. 1. С. 300.
} 
жизни страны. Это несоответствие можно было увидеть уже в период издания Жалованной грамоты городам 1785 г., в которой императрица была вынуждена отказаться от простой и логичной организации городского сословия, ранее сформированной и закрепленной в Регламенте Главного Магистрата Петра I. На смену петровской категории «граждан», делившихся на регулярных и нерегулярных, в которой первые дополнительно подразделялись на гильдии ${ }^{11}$, пришло весьма запутанное разделение жителей города на 6 разрядов. Эти 6 разрядов формировались по различным основаниям, и нередко один и тот же человек мог оказаться в двух различных разрядах одновременно ${ }^{2}$. Такая замена объяснялась потребностями более правильного налогообложения городских жителей в условиях усложнения социальной структуры общества. Формирование городской буржуазии не могло быть отражено в рамках сложившейся сословной организации, а отказаться от неё правительство не было готово. Значит, требовалось соединить несоединимое: с одной стороны, сохранить сословное деление общества, а с другой - учесть реальную роль в экономической жизни города «новых богачей», финансовые средства которых, на взгляд властей, «так и просились» под обложение повинностями. Возникнув к концу XVIII в., это несоответствие юридической формы и экономического содержания тем более заметно стало проявляться к середине следующего XIX столетия.

В то время, согласно законодательству, население страны состояло из двух основных групп: природные обыватели и инородцы. Официальной основой для такого подразделения являлось «резкое различие в степени культуры», а также «низкое гражданское развитие инородцев» ${ }^{13}$. Самих же природных обывателей России закон делил на четыре главных рода людей: дворянство, духовенство, городские обыватели и сельские обыватели.

Дворянство представляло собой замкнутую касту, доступ в которую был чрезвычайно затруднен $^{14}$. Оно сохраняло многочисленные привилегии, унаследованные от прошлого. Значительная часть высших чиновников и центральных министерств, и местной администрации происходила из дворян, как личных, так и наследственных. Из дворян происходили почти все старшие офицеры императорской армии. Не дворянин путём многолетней службы к моменту выхода на пенсию мог в лучшем случае достичь звания штабс-капитана, не выше. Но подлинным ядром этого сословия было дворянство поместное, землевладельческое, которое в обладании имениями видело гарантии своего материального благополучия и «независимости».

Обыватели городские делились, прежде всего, в зависимости от принадлежащего им капитала и рода профессиональных занятий: на почетных граждан, купцов, цеховых ремесленников, мещан и рабочих людей. Почетные граждане - потомственные и личные пользовались, подобно дворянам, рядом привилегий: освобождались от телесных наказаний, от личных принудительных работ, имели свободу передвижения.

В купцы записывались люди, платившие особые гильдейские пошлины: оптовые торговцы выправляли свидетельство по первой гильдии, что стоило свыше 500 руб., а занимающиеся розничной торговлей - по второй гильдии. Купцы пользовались почти теми же привилегиями, что и почетные граждане. Наиболее «успешные» из них могли рассчитывать на почётные звания, такие как «коммерции советника», или «мануфактур-советника».

\footnotetext{
${ }^{11}$ Регламент или Устав главного магистрата 16 января 1721 года // Реформы Петра I. Сборник документов / сост. В.И. Лебедев. М.: Гос. соц.-эк. изд-во, 1937. С. 192-193.

${ }^{12}$ Например, в разряд так называемых «настоящих городовых обывателей» включались все лица, являвшиеся собственниками дома или участка городской земли независимо от их сословного статуса, а вот последующие разряды формировались уже по сословной принадлежности. См.: Грамота на права и выгоды городам Российской империи от 21 апреля 1785 года // Российское законодательство X - XX веков: в 9 т. Т. 5. С. 81-82.

${ }^{13}$ Коркунов Н. М. Русское государственное право. Т. І: Введение и общая часть. 3-е изд., перераб. СПб.: Тип. M.M. Стасюлевича, 1899. С. 207, 252. Фактически тем самым закон закреплял этот недостаточный уровень гражданского развития этих самых «инородцев».

${ }^{14}$ Реальная возможность приобрести дворянское звание путем выслуги или получения высоких наград, как это было установлено Петром I, фактически отпала. Так, ко второй половине XIX в., после реформ, проведённых Николаем I, для получения звания потомственного дворянина, которое, в отличие от личного дворянства передавалось не только жене, но и детям, нужно было дослужиться до чина полковника или капитана 1-го ранга, а для гражданских чиновников приобрести чин действительного статского советника. Кроме того, в потомственные дворяне попадали кавалеры всех российских орденов I степени и ордена Владимира трех степеней. Для абсолютного большинства чиновников, особенно обитавших в провинции, это были совершенно запредельные требования.
} 
Дальше шли так называемые цеховые, куда зачислялись все ремесленники, делившиеся на мастеров и подмастерьев.

Основную же массу городского населения составляли мещане, не включенные в отмеченные выше категории, а потому и не пользовавшиеся никакими привилегиями.

В самом низу этой социальной лестницы располагались «рабочие люди» ${ }^{15}$.

Самое многочисленное сословие страны - крестьянство, отнесенные реформой 1861 г. к разряду «свободных сельских обывателей», в свою очередь разбивалось на несколько разрядов.

Такое деление общества, как уже говорилось выше, не соответствовало реально сложившемуся подразделению его по классам и социальным группам, что тормозило дальнейшее развитие страны. Например, традиционные привилегии дворян, облегчавшие им поступление на командные должности в армии и карьеру на военной службе, сдерживали рост численности и качественную эволюцию офицерского корпуса. Затруднение не дворянам поступать в военно-учебные заведения не позволяло создать достаточный резерв офицеров запаса. А без такого резерва невозможным становилось создание массовой армии, построенной на основе воинской повинности, а не рекрутского набора, оставляло значительную часть потенциальных призывников вне военного обучения (их относили к категории так называемых «ратников», которые должны были обучаться только при призыве в военное время).

Сохранение сословных законов относительно крестьянства вело к игнорированию возникшего в его среде слоя «капиталистых крестьян». А ведь именно из них постепенно составлялась значительная часть нарождавшейся промышленной буржуазии. Параллельно с промышленной буржуазией постепенно складывался, преимущественно также из среды крестьянства, промышленный пролетариат. Но учёт, а тем более защита интересов этих новых социальных групп оказывались вне поля зрения правительства империи, что вело к обострению социальных противоречий, прежде всего между ними. Цивилизованные способы разрешения классовых противоречий, в данных условиях, оказывались невозможными, поскольку официальное законодательство любой трудовой конфликт рассматривало как «бунт против властей, установленных».

Между тем сохранение отжившего сословного деления людей, власти считали своей обязанностью. Это обстоятельство сказалось и на проводимой судебной реформе. Официально провозглашённый принцип равного и всесословного характера нового суда был нарушен уже в самих Судебных Уставах от 20 ноября 1864 г. Введённый ими суд с участием сословных представителей был одним из наглядных проявлений непоследовательности преобразований. «Замахнувшись» на множественность судов, созданных в екатерининскую эпоху для обслуживания дворян, купцов, ремесленников, крестьян и других сословий, власти не решились полностью изолировать новые суды от влияния сословных интересов. Были выделены категории преступлений, рассмотрение дел о которых ставилось под контроль представителей основных сословий. К таким преступлениям относились, например, дела о государственных преступлениях, о преступлениях по должности.

При их разбирательстве к профессиональным судьям присоединялись предусмотренные законом четыре сословных представителя - губернский и уездный предводители дворянства, городской голова и волостной старшина. Закон допускал некоторое изменение такого состава сословных представителей: в рассмотрении дела мог участвовать не сам губернский предводитель дворянства, а ктото другой, кому доверялось выполнить эту миссию от имени дворянского собрания. Но при этом сословные представители не избирались, а участвовали в судопроизводстве исключительно в силу занимаемой должности. Очередность исполнения этой обязанности устанавливалась судебной палатой на основе списков, ежегодно предоставляемых губернатором.

Сословные представители участвовали в вынесении приговоров, пользуясь теми же правами, что и профессиональные судьи. При постановлении приговоров они заседали все вместе, решая и вопрос о том, виновен ли данный подсудимый в совершении преступления, в котором его обвинили, и о том, подлежит ли он наказанию, а если подлежит, то какому. Рассмотрение уголовных дел с участием сословных представителей осуществлялось не только в окружных судах, но и в судах других инстанций общих судебных установлений - в судебных палатах и Правительствующем Сенате.

Чем же объяснялось нарушение основополагающих принципов Судебной реформы? В основе этих нарушений лежало элементарное недоверие самодержавной власти к обществу. Так, например, в журнале Государственного Совета утверждалось: «В той среде нашего общества, из которой предпо-

\footnotetext{
${ }^{15}$ Разумеется, говорить о капиталах этой последней группы городского населения нельзя.
} 
лагается назначать большинство присяжных, встречаются ошибочные понятия о государственном устройстве» ${ }^{16}$. Отсюда делался вывод, что «присяжным следует предоставить рассмотрение только тех дел, по которым от них можно ожидать приговоров безошибочных». Иначе власть и государство «останутся без защиты» ${ }^{17}$.

В Судебных Уставах, в которых был провозглашен принцип равенства всех перед законом, имелись статьи, согласно которым «приговоры о лишении всех прав состояния или всех особенных прав и преимуществ дворян, чиновников, священнослужителей подлежат быть представленными на высочайшее усмотрение, ибо почетными преимуществами дворянства, основанными на высочайше дарованных грамотах, должно дорожить...» ${ }^{18}$.

Такое восприятие самодержавием общества как чего-то несамостоятельного, постоянно нуждающегося в опеке возникло не на пустом месте. Это был своеобразный отзвук прогрессивных реформ минувшего XVIII в., когда, по словам А.С. Пушкина, «правительство было единственным европейцем в России» 19 . Однако идеология «просвещённого абсолютизма» к середине ХІХ столетия полностью себя исчерпала. Классовая структура общества приобретала характер, всё более обычный для Европы того времени. Новые классы обладали собственными интересами и стремились отстаивать их самостоятельно. Такая самостоятельность не была чем-то случайным, сродни капризам, хотя правительством зачастую воспринималась именно в таком духе.

Имперская бюрократия, в руках которой находились все нити управления огромной державой, традиционно связывала свои надежды и перспективы именно с дворянством, причём в первую очередь с дворянством поместным. Поскольку введённая Петром I Табель о рангах, по крайней мере формально, позволяла выходцам из «неблагородных сословий» достигать статуса «личных», а затем и «потомственных дворян», значительная часть государственных чиновников, особенно служивших в столицах империи, надеялась со временем всё же добиться вожделенного дворянского звания. Поэтому бюрократы серьёзно относились к требованиям дворянства, частью которого они себя воспринимали, в то время как интересы других социальных слоёв тогдашнего общества находились как бы на периферии или и вовсе вне поля их зрения.

Именно по этой причине самодержавное государство игнорировало интересы непривилегированных слоёв общества, полагая, что оно лучше самих подданных знает, что им нужно. Опираясь на это «знание», оно навязывало новым социальным слоям собственное понимание их интересов и потребностей. А это в свою очередь вело в будущем к самым серьёзным негативным последствиям. Молодая русская буржуазия оказалась не самостоятельной, «привязанной» в экономическом и идеологическом отношении к самодержавному государству. В результате, в период революционных потрясений следующего XX в. она не сумела создать свои собственные, самостоятельные государственные структуры, упорно стремясь к максимально возможному сохранению царской бюрократии и связанного с нею поместного землевладения. Поэтому традиционную роль буржуазии по ликвидации феодальных пережитков пришлось выполнять другим общественным силам. Именно данное обстоятельство предопределило необычный характер русской революции 1917 г., когда ликвидация феодальных элементов осуществлялась уже сторонниками социалистического выбора развития России. Это в свою очередь повлияло и на особенности строительства уже новой, социалистической государственности.

Таким образом, анализ «самой буржуазной» из реформ Александра II позволяет выявить необычный аспект «отсталости царской России». Отсталости не экономической или социальной, а скорее, концептуально-идеологической. Царизм оказался не способен к восприятию новых идей, оставаясь в плену идеологии «просвещённого абсолютизма» XVIII столетия. Идеологии, не позволившей ему осознать своё новое место в изменившемся мире и вместо приспособления к новым реалиям толкнувшей его на создание идеологических фантомов типа «теории официальной народности». Что в свою очередь исключило всякую возможность его преобразования в нормальную буржуазную конституционную монархию в ХХ в.

Поступила в редакцию 12.04.2020

\footnotetext{
${ }^{16}$ Материалы по судебной реформе в России 1864 года. СПб., 1864. Т. 19. С. 234.

${ }^{17}$ Там же.

${ }^{18}$ Шевчук В.Б. Реформирование судебной системы России во второй половине ХIX - нач. XX в. (историкоправовое исследование): дис. ... канд. юрид. наук. СПб., 2004. С. 45.

${ }^{19}$ Пушкин А.С. - Чаадаеву П.Я. Неотправленное письмо от 19 октября 1836 г. (черновик) / пер. с фр. // Пушкин А.С. Собрание сочинений: в 10 т. М., 1982. Т. 10. С. 468.
} 
Евсеенко Тимур Петрович, доктор юридических наук, профессор кафедры теории и истории государства и права ФГБОУ ВО «Удмуртский государственный университет» 426034, Россия, г. Ижевск, ул. Университетская, 1 (корп. 4) E-mail: timur.evseenko@yandex.ru

\section{T.P. Evseenko}

\section{TO THE DISCUSSION OF THE PROSPECTS FOR THE EVOLUTION OF THE RUSSIAN AUTOCRACY} INTO A BOURGEOIS MONARCHY (ON THE EXAMPLE OF THE JUDICIAL REFORM OF 1864)

DOI: $10.35634 / 2412-9593-2020-30-3-375-381$

The article deals with the problem of opportunities for reforming the social and state system of the Russian autocracy. The example of the Judicial reform of 1864 shows the limits of the tsarism's ability to reform. The author considers the preservation of the class system in the Russian Empire as the main reason for incomplete reforms. The desire to preserve the privileges of the nobility by any means did not allow the government to realize the real needs of society. Without seeing the emergence of new social classes, the government could not protect their interests. At the same time, the autocracy imposed on society its understanding of its interests. This policy has led to a distortion of the ideological development of the Russian bourgeoisie, making it unable to independently protect even the most important of its own interests. Therefore, the tasks of the bourgeois-democratic revolution had to be solved by other, anti-bourgeois forces in the course of the socialist revolution.

Keyword: Russian Empire, Judicial reform of 1864, Russian liberalism, class system, jury, class representatives in court.

Received 12.04.2020

Evseenko T.P., Doctor of Law, Professor at Department of the theory and history of state and law Udmurt State University

Universitetskaya st., 1/4, Izhevsk, Russia, 426034

E-mail: timur.evseenko@yandex.ru 